\title{
WHITMAN, EMERSON, AND "THE BALLAD OF THE ABOLITION BLUNDER-BUSS"
}

\section{LEN Gougeon}

IT IS GENERALLY KNOWN that Ralph Waldo Emerson suffered considerable social embarrassment, as well as public and private criticism, as a result of his relationship with Walt Whitman. This criticism began with Whitman's publication of Emerson's famous letter greeting him at the beginning of a great career. Many of Emerson's friends and associates objected to the "frank, fleshy passages" of the work and marvelled at Emerson's support of it. ${ }^{1}$ This criticism continued unabated over the years. Thus, when Whitman briefly took up residence in Boston in the spring of 1860 to oversee the publication of Leaves of Grass there, Emerson wished to take him to a gathering of the Saturday Club. Unfortunately, several members objected and the plans were dropped. ${ }^{2}$ And when the Boston edition of Leaves was published, a reviewer in the Boston Post stated at the time, "the most charitable conclusion at which we can arrive is that both Whitman's Leaves and Emerson's laudation had a common origin in temporary insanity." 3

For the most part, then, it would seem that Whitman gained much as a result of Emerson's persistent association and support, and that Emerson consistently paid the price for it. However, in at least one instance, the opposite was true. Whitman's association with Emerson, especially in the spring of 1860 in Boston, drew him into a controversy which was rocking American society and caused him, along with Emerson, to become the object of public satire and ridicule. That controversy was the abolition cause.

Although he was a."decided anti-slavery believer," Whitman was never a strong supporter of the abolition movement. Somewhat like Emerson in his earlier years, Whitman objected to the apparent myopia of the abolitionists who were "consumed by the notion ... that slavery - slavery alone-was evil, and the universe contained no other." 4 When the abolition movement became more prominent in the $1840 \mathrm{~s}$, Whitman came to consider abolition oratory as "ranting" which served to support an "abominable fanaticism." As one recent biographer puts it, "the chief issue for Whitman was not black slavery in itself but the oppression of spirit that black slavery, and all the other forms of servitude, fostered in what Emerson called 'the republic of Man."'5 Indeed, a recent article suggests further that, while Whitman's poetry "exalted the classic ideal of the equality of all men, ... his political writing seriously undercut the democratic pronouncements of his verse." The author argues that, overall, Whitman's "attitude toward slavery and blacks demonstrates that he was both ambivalent and opinionated."6 Similarly, another critic insists that "the War always seemed to Whitman to be 
less an effort to free the slave than a struggle to liberate the common man, the average northerner, the quintessential American."7

Unlike Whitman, however, Emerson had grown much closer to the organized abolitionists throughout the 1850 s. After overcoming the initial ambivalence which had characterized his earliest relationship with the abolitionists, Emerson, by the spring of 1851 , was clearly associated with their ranks. ${ }^{8}$ Following the passage of the Fugitive Slave Law in 1850, and other outrages such as the attack on Sumner in 1856 and the execution of John Brown in 1859, Emerson became more outspoken than ever. In an address titled "Courage" which he delivered in Boston on 8 November 1859, Emerson spoke of John Brown as "that new saint, than whom none purer or more brave was led by love of men into conflict and death, - the new saint awaiting his martyrdom, and who ... will make the gallows glorious like the cross." (Emerson did not, however, include this statement in the published version of the address.) Following Brown's execution Emerson would memorialize him in a speech delivered in Salem in January of 1860, as "a romantic character absolutely without any vulgar trait; living to ideal ends, without any mixture of self-indulgence or compromise." 10 For his part, Whitman recognized Brown's martyrdom, but did not allow it to "spoil his supper" because, as he remarked to Horace Traubel, "I see martyrdoms wherever I go. ... Why should I go off emotionally half-cocked only about the ostentatious cases?" 11

The execution of John Brown served to inflame passions throughout the North regarding the abolition question. As secession and civil war loomed ominously on the horizon, animosity towards blacks and abolitionists became acute in part because in the conservative press they were depicted as somehow responsible for provoking these developments. As one historian puts it, "at no time since the 1830s had abolitionists been subjected to such virulent mob violence as in the secession winter of $1860-1861$. On 3 December 1860 an abolitionist meeting in Boston was stormed by a mob of 'North end Roughs and Beacon Street Aristocrats' led by lawyers and merchants.'” These rowdies stormed the platform, removed the speaker, who was James Redpath, a strong supporter of John Brown, and broke up the meeting. ${ }^{12}$ After this, mobs assaulted blacks, who had attended other abolition meetings, and smashed windows in the Negro section of the city. Despite such violence, the abolitionists were determined not to be dissuaded from their cause at the moment when victory seemed within reach. Thus, Oliver Johnson wrote to Wendell Phillips in December of 1860, "I take it mob law is not to be revived in Boston. The pro-slavery 'gentlemen of property and standing' are now too weak to wield that instrument successfully. If they persist in trying the experiment they'll surely find that 1860 is not $1835 . " 13$ And so the struggle grew more intense. James Redpath, the subject of the violence noted above, had recently published his book, The Public Life of Captain 
fohn Brown, and dedicated it to "Wendell Phillips, Ralph Waldo Emerson, and Henry D. Thoreau, Defenders of the Faithful, who, when the mob shouted, 'Madman!' said, 'Saint.'"14 Later in 1860, Redpath edited a collection of memorial speeches on John Brown titled Echoes of Harper's Ferry which included Emerson's own Salem oration. Both of Redpath's books were printed by Thayer \& Eldridge Whitman's Boston publisher.

Despite all of the agitation that was shaking Boston in the spring of 1860 and later, Whitman seems to have remained largely aloof from the controversy. Among the many new friends and acquaintances that he made while in Boston were several prominent abolitionists: James Redpath; John Townsend Trowbridge, poet and abolitionist novelist; William Douglas O'Connor, whose abolition novel Harrington was also being published by Thayer \& Eldridge; and Emerson's Concord neighbor and fellow abolitionist, Franklin Sanborn. ${ }^{15}$ Regarding O'Connor, Whitman would later write, "he was a gallant, handsome, gay-hearted, fine-voiced, glowing-eyed man; lithe moving on his feet, of healthy and magnetic atmosphere and presence, the most welcome company in the world." Whitman's only concern about O'Connor was that "he was a thorough-going anti-slavery believer, speaker, and writer, (doctrinaire,) and though I took a fancy to him from the first, I remember I fear'd his ardent abolitionism - was afraid it would probably keep us apart." 16

The only instance where Whitman demonstrated any interest in the abolition activities of these individuals was his attendance at Franklin Sanborn's court hearing. Sanborn was an early supporter of John Brown's activities. As secretary of the Massachusetts "Kansas Committee" he became deeply involved with Brown's efforts to confront violently the pro-slavery forces. As a member of the group known as the "Secret Six," Sanborn, it is assumed, had advance knowledge of Brown's planned raid on the federal arsenal at Harpers Ferry. ${ }^{17}$ When the Mason Committee of the United States Senate was established to investigate the raid, agents were sent to Massachusetts to arrest Sanborn and to force his appearance as a witness. Sanborn was determined not to cooperate and when the federal deputies arrived in Concord on the evening of 3 April 1860 to arrest him, a fracas occurred. ${ }^{18}$ Among the many Concordians who responded to Sanborn's shouts for help was Ralph Waldo Emerson. ${ }^{19}$ Eventually the deputies were driven off and the following morning Judge Lemuel Shaw released Sanborn on the grounds that the officers had no jurisdiction in Massachusetts.

In his own account of the court proceedings, recorded some years later, Sanborn remarks, "I sat in the Old Court House listening to the arguments, and as I sat there saw an extraordinary man sitting near the door, wearing a carpenter's jacket, grey or blue-a very striking looking person. . . . A few days later, I was in Boston, and went round to the publishing office of Thayer \& Eldridge, and there sitting on the counter was this extraordinary person I had seen in the Courthouse. I was introduced to him. He was Walt Whitman. 
My personal acquaintance began at that time."20 Later, Whitman would tell Sanborn that his interest in attending the proceeding was to see that justice was done him. ${ }^{21}$ However, since Whitman did not know Sanborn prior to this event, and since he had no strong interest in abolition affairs, it seems more likely that he attended the court proceedings out of curiosity regarding a development which had become a cause célèbre, at least among his newfound Boston friends. Indeed, he may even have accompanied some of them there.

Throughout his stay in Boston Whitman was apparently amused by the socialization of blacks in the community. The tenor of his remarks, recorded in his Boston Notebook, suggests that, in his perception, blacks enjoyed a greater degree of freedom in Boston than elsewhere. It also seems that his own attitude was becoming more liberal in his response to this experience. For example, he observes that "You see not near as many black persons in Boston as you would probably expect; they are not near as plenty as in New York or Philadelphia. Their status here, however, is at once seen to be different. I have seen one worker at case in a printing office ... . and no distinction made between him and the white compositors. Another I noticed ... [was] an employee in the State House, apparently a clerk or under-official of some such kind." In addition to these advantages in employment, Whitman also notes that blacks in Boston seem to move more freely in society. He states that "at the eating-houses, a black, when he wants his dinner, comes in and takes a vacant seat wherever he finds one-and nobody minds it. I notice that the mechanics and young men do not mind all this, either." (It is worthwhile to note that Whitman's observations contrast sharply with those that his friend O'Connor presents in Harrington, where Boston Negroes are depicted as limited to "a narrow range of humble employments and avocations" and "excluded from almost everything."22) Interestingly enough, Whitman's immediate reaction to this experience seems to suggest that it was something of a revelation. He says, "I am too much a citizen of the world to have the least compunction about it," and he concludes with the observation that "the blacks here are certainly of a superior order - quite as good to have in contact with you as the average of "our own color."'23

With the printing of his book complete, Whitman departed from Boston around the middle of May. ${ }^{24}$ In his absence the abolition controversy continued to simmer. Emerson's participation in events would climax on 24 January 1861 when he was booed from the stage at the Tremont Temple while attempting to deliver an abolition address. His own opinion of the experience he summed up with the statement, "I went, and, though I had nothing to say, showed myself. If I were dumb, yet I would have gone and mowed and muttered or made signs. The mob roared whenever I attempted to speak, and after several beginnings, I withdrew."25

Shortly after Emerson's abortive performance, a scurrilous satirical work 
called the "Ballad of the Abolition Blunder-buss" was published in Boston by L. M. Sargent. ${ }^{26} \mathrm{Mr}$. Sargent was a successful businessman, a committed proponent of the cause of temperance, and a virulent anti-abolitionist. One of the main targets of his attack, as indicated in the two cartoons reproduced below, was R. W. Emerson. One of the cartoons makes specific reference to Emerson's Tremont Temple performance and his effort to "ingratiate himself to his Boston audience by recalling his Boston origin." 27 The other cartoon, however, is obviously an attempt to cast aspersions not only on Emerson, but also on "Walt. Whitman," author of "Leaves of Grass." Since, as we have seen, Whitman himself was no partisan of the abolition cause, the likeliest explanation for his inclusion in this attack on Emerson's abolitionism would seem to be his own association with the New England bard, which, as indicated above, was noted by the local press and others. If this is the case, then it represents the only known instance where the "rude and barbaric" Whitman suffered public ridicule as a result of his association with the New England "saint."

\section{The University of Scranton}

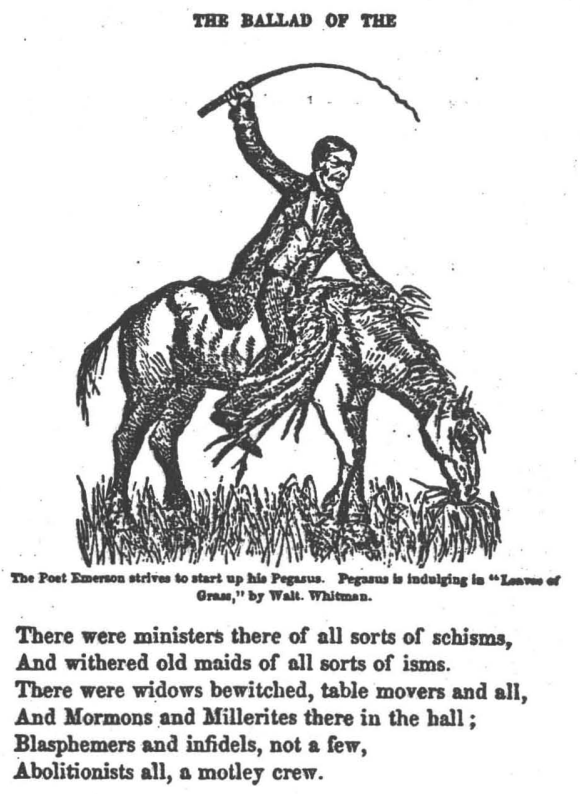

ABULTTIOS BLUNDER-BUSE.

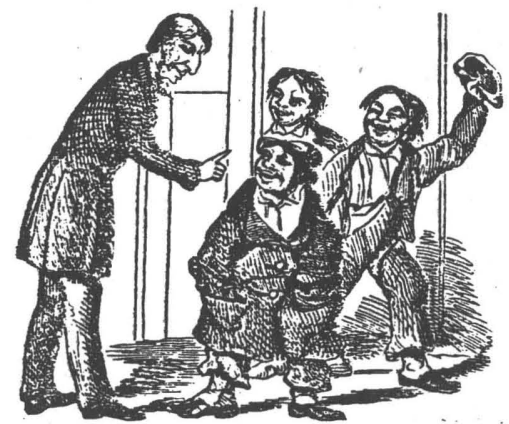

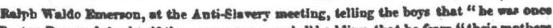
- Bonton Boy, and donbte if ther ean my as much," adding, that he fears "their motbers don't knew thes are out."

Who takes so much pains

To show he 's no brains,

That nobody now. is obliged for his pains.

A man all made up of malice and spleens ;-

In the summer he eats anti-slavery greens,

In the winter he bakes anti-slarery beans;

He lives by his wits - and that's on small means.

1 The Eumblebee Poet here Intimatee that the boya are of Iriab diatswettion. 


\section{NOTES}

1 Ralph Rusk, The Life of Ralph Waldo Emerson (New York: Charles Scribner's Sons, 1949), p. 373.

2 Gay Wilson Allen, The Solitary Singer: A Critical Biography of Walt Whitman (New York: The Macmillan Co., 1955), p. 238.

3 Jerome Loving, Emerson, Whitman, and the American Muse (Chapel Hill: University of North Carolina Press, 1982), p. 107.

4 Quoted by Oscar Cargill in "Walt Whitman and Civil Rights," in Essays in American and English Literature, ed. Max F. Schulz, et al. (Athens: Ohio University Press, 1967), p. 55.

5 Justin Kaplan, Walt Whitman, A Life (New York: Bantam Books, 1980), p. 133.

6 Ken Peeples, Jr., "The Paradox of the 'Good Gray Poet' (Walt Whitman on Slavery and the Black Man)," Phylon, 35, No. 1 (1974), 31, 32.

7 M. Wynn Thomas, "Whitman and the American Democratic Identity Before and During the Civil War," fournal of American Studies, 15, No. 1 (1981), 77.

8 For a discussion of the evolution of Emerson's abolitionism in the 1840s and 1850s see Len Gougeon, "Emerson and Abolition: The Silent Years, 1837-1844," American Literature, 54 (1982), 560-575; and "Emerson and Furness: Two Gentlemen of Abolition," American Transcendental Quarterly, 41 (1979), 17-31.

9 James Elliot Cabot, A Memoir of Ralph Waldo Emerson (Boston: Houghton, Mifflin and Company, 1887), 2:597.

10 Ralph Waldo Emerson, The Complete Works of Ralph Waldo Emerson, ed. Edward Emerson (Boston: Houghton, Mifflin and Company, 1903), 11:279.

11 Horace Traubel, With Walt Whitman in Camden (New York: D. Appleton and Company, 1908), 2:486.

12 Merton Dillon, The Abolitionists: The Growth of a Dissenting Minority (New York: W. W. Norton \& Company, 1974), p. 250.

137 December 1861, Manuscript, Houghton Library, Harvard University.

14 Rusk, p. 403.

15 See Allen, p. 240, and Kaplan, pp. 254-255.

16 Walt Whitman, Prose Works 1892, ed. Floyd Stovall (New York: New York University Press, 1964), 2:689-690.

17 Harry Clarkson, "Mentions of Emerson and Thoreau in the Letters of Franklin Benjamin Sanborn," in Studies in the American Renaissance, ed. Joel Myerson (Boston: G.K. Hall, 1978), p. 390.

18 Ruth W. Wheeler, Concord: Climate for Freedom (Concord: Concord Antiquarian Society, 1967), pp. 190-191.

19 Edith Emerson, The Letters of Edith Tucker Emerson, ed. Edith Gregg (Kent State: Kent State University Press, 1982), 2:212-213.

20 Franklin Sanborn, "Whitman and Emerson," in Transcendental and Literary New England, ed. Kenneth Walter Cameron (Hartford: Transcendental Books, 1975), pp. 202-203. 
21 Allen, p. 242.

22 Jerome Loving, Walt Whitman's Champion, William Douglas O'Connor (College Station: Texas A \& M University Press, 1978), p. 38.

23 Walt Whitman, Notebooks and Unpublished Prose Manuscripts, ed. Edward F. Grier (New York: New York University Press, 1984), 1:422.

24 Allen, p. 243.

25 Rusk, p. 409.

26 Lucius M. Sargent, The Ballad of the Abolition Blunder-buss (Boston, 1861). I wish to express my gratitude to the staff of the Concord Free Public Library, especially Mrs. Marcia Moss, for bringing this work to my attention.

27 Rusk, p. 409. 